\title{
Media Pembelajaran Audio Visual Berbasis Konservasi Lingkungan pada Topik Siklus Air Kelas V SD
}

\author{
Komang Diah Purnami ${ }^{*}$, Ni Ketut Suarni² \\ 1,2 Pendidikan Guru Sekolah Dasar, Universitas Pendidikan Ganesha, Singaraja, Indonesia
}

\section{AR T I C L E I N F O}

Article history:

Received July 28, 2021

Revised July 30, 2021

Accepted October 30, 2021

Available online December 25, 2021

Kata Kunci

Media, Audio, Visual, Konservasi,

Lingkungan

Keywords:

Media, Audio, Visual, Conservation Environment

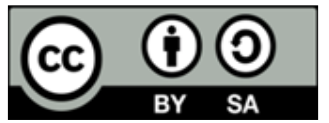

This is an open access article under the CC BY-SA license.

Copyright $(2021$ by Author. Published by Universitas Pendidikan Ganesha.

\begin{abstract}
A B S T R A K
Metode pemberian tugas yang masih dominan digunakan oleh guru dan sulitnya menanamkan nilai karakter selama kegiatan belajar dari rumah, membuat pelaksanaan proses pembelajaran kurang efektif. Penelitian ini bertujuan untuk menciptakan produk media pembelajaran audio visual berbasis konservasi lingkungan untuk siswa kelas V SD dan mengembangkan media pembelajaran audio visual berbasis konservasi linkungan yang teruji validitasnya. Penelitian ini mengacu pada prosedur model pengembangan 4D. Subjek uji coba penelitian yaitu 4 pakar $(2$ dosen pembimbing, pakar desain dan media pembelajaran), 2 praktisi, dan 22 siswa kelas V SD (6 orang siswa untuk respon perorangan, dan 16 orang siswa untuk respon kelompok kecil). Metode yang digunakan untuk mengumpulkan data adalah metode kuesioner. Instrumen yang digunakan dalam mengumpulkan data yaitu kuesioner. Teknik yang digunakan untuk menganalisis data yaitu deskriptif kualitatif dan deskriptif kuantitatif. Data hasil validasi pakar dianalisis dengan menggunakan rumus indeks validasi Aiken, serta menghitung rata-rata skor respon praktisi dan siswa. Hasil analisis data validitas pakar dari aspek isi materi berada pada rentang 0,813 - 1 , aspek desain pembelajaran berada pada rentang $0,813-1$, sedangkan aspek media pembelajaran berada pada rentang 0,938 - 1. Hal ini menandakan bahwa validitas isi produk tinggi. Uji respon praktisi memperoleh skor rata-rata 4,97, rata-rata skor respon siswa perseorangan 4,83, dan respon siswa kelompok kecil yaitu 4,89 . Hal ini berarti semua aspek uji respon terhadap produk memiliki kualifikasi sangat baik. Berdasarkan hasil analisis tersebut, media pembelajaran audio visual berbasis konservasi lingkungan layak digunakan pada topik siklus air kelas V SD.
\end{abstract}

A B S T R A C T

The method of assigning assignment is still dominantly used by teachers and the difficulty of instilling character values during learning activities from home makes the implementation of the learning process less effective. This study aims to create environmental conservation-based audio-visual learning media products for fifth grade elementary school students and to develop environmental conservation-based audio-visual learning media whose validity has been tested. This research refers to the 4D development model procedure. The subjects of the research trial were 4 expert (2 supervisors, design experts and instructional media), 2 practitioners, and 22 fifth grade elementary school students (6 students for individual responses, and 16 students for small group reponses). The method used to collect data is a questionnaire method. The instrument used in collecting data is a questionnaire. The technique used to analyze the data is descriptive qualitative and descriptive quantitative. The data from the expert validation results were analyzed using the Aiken validation index formula, and calculated the average practitioner and student response scores. The results of the analysis of expert validity data from the aspect of material content are in the range of 0,813-1, the learning design aspect is in the range of 0,813 - 1, while the learning media aspect is in the range of $0,938-1$. This indicates that the content validity of the product is high. The practitioner response test obtained an average score 4,97, the average score of individual student responses was 4,83, and the response of small group students was 4,89. This means that all aspects of the product response test have very good qualifications. Based on the results of the analysis, audio-visual learning media based on environmental conservation is appropriate for use on the topic of the fifth grade of elementary school water cycle. 


\section{PENDAHULUAN}

Penutupan sementara lembaga pendidikan sebagai upaya dalam pencegahan penyebaran Pandemi Covid-19 berdampak pada perubahan pelaksanaan proses pembelajaran (Jena, 2020; Mastura \& Santaria, 2020). Proses pembelajaran awalnya dilaksanakan secara luring, namun kini dilaksanakan secara daring, sehingga pemanfaatan teknologi sangat dibutuhkan (Mishra et al., 2020; Wardani \& Ayriza, 2020). Guru dalam melaksanakan proses pembelajaran daring perlu melakukan berbagai inovasi seperti memanfaatkan berbagai aplikasi dan media berbasis teknologi (Damsa et al., 2021; Selvaraj et al., 2021). Selain guru, orang tua juga dituntut mampu membimbing anaknya selama proses pembelajaran daring (Solekhah, 2020; Wardani \& Ayriza, 2020). Namun kenyataannya, baik guru, maupun orang tua siswa memiliki kendala dalam melaksanakan pembelajaran daring (Dong et al., 2020; Mastura \& Santaria, 2020). Bagi orang tua, kendala yang dirasakan adalah sulit membimbing anaknya karena kurangnya pemahaman materi (Jena, 2020; Wardani \& Ayriza, 2020). Sedangkan bagi guru, adanya Pandemi Covid-19 merupakan hal yang darutan, sehingga persiapan yang dilakukan pun kurang yang menyebabkan proses pembelajaran difokuskan dalam bentuk penugasan (Handayani \& Gafur, 2020; Jena, 2020; Satrianingrum \& Prasetyo, 2020). Selain itu, berdasarkan analisis awal diperoleh guru masih kesulitan dalam mengintegrasikan nilai-nilai karakter seperti konservasi lingkungan dengan materi pembelajaran. Apalagi berdasarkan hasil wawancara menyatakan masih banyak siswa yang kurang peduli terhadap lingkungan.

Berdasarkan permasalahan tersebut, diperlukan sebuah solusi untuk membantu siswa dalam memahami pelajaran, meningkatkan motivasi belajar siswa, serta mengintegrasikan nilai peduli lingkungan pada materi pelajaran. Adapun solusi yang dilakukan yaitu dengan mengembangkan media pembelajaran yang memanfaatkan teknologi dan berbasis dengan nilai karakter upaya pelestarian lingkungan, sehingga media pembelajaran tersebut dapat membantu guru dalam menyampaikan pesan kepada siswa (Rahayu et al., 2020; Safitri \& Koeswanti, 2021). Disertakannya media pembelajaran dalam proses pembelajaran maka pembelajaran akan lebih efisien dan efektif (Andriani et al., 2019; Aulia et al., 2020). Selain itu, media pembelajaran juga dapat meningkatkan minat belajar dan membantu pemahaman siswa terhadap materi pembelajaran (Maulidah \& Syakur, 2018; Sari \& Setiawan, 2018). Salah satu media pembelajaran yang memanfaatkan teknologi, serta dapat menyajikan nilai peduli lingkungan dengan memberikan contoh nyata adalah media pembelajaran audio visual, karena media audio visual memiliki kombinasi audio dan visual yang dapat memberikan suasana serta emosi kepada siswa (Andersen et al., 2021; Saputri et al., 2018). Media audio visual memiliki beberapa kelebihan diantaranya dapat menambah pengalaman, menyajikan gambaran secara konkret, dapat menjadi pemacu minat belajar siswa, baik untuk pencapaian tujuang belajar pengetahuan, sikap, maupun keterampilan, serta mudah diingat (Winarto et al., 2020; Yazar \& Arifoglu, 2012).

Temuan penelitian sebelumnya juga menyatakan media audio visual dapat meningkatkan motivasi belajar siswa (Pradilasari et al., 2019; Sutrisno, 2020). Penelitian yang menunjukkan bahwa media video pembelajaran layak digunakan untuk meningkatkan hasil belajar siswa(Hidayati et al., 2019; Suryansah \& Suwarjo, 2016). Penelitian yang menyatakan bahwa media video dapat membantu siswa dalam memahami kosakata (Pattemore \& Muñoz, 2020; Silverman et al., 2019). Penelitian yang dilakukan oleh (Herff et al., 2019; Karlina \& Setiyadi, 2019) menyatakan media pembelajaran audio dan visual dapat membantu daya ingat siswa. Penelitian yang menunjukkan bahwa media pembelajaran video dapat membantu guru dalam mentransfer pesan, meningkatkan motivasi siswa, menciptakan suasana yang menyenangkan, serta dapat meningkatkan prestasi dan kemampuan berpikir siswa (Putri et al., 2020; Winarto et al., 2020). Namun, belum ada kajian secara mendalam mengenai media pembelajaran audio visual yang berbasis dengan konservasi lingkungan pada topik siklus air kelas $\mathrm{V}$ sekolah dasar. Melalui pengembangan media pembelajaran audio visual berbasis konservasi lingkungan pada topik siklus air kelas V sekolah dasar, dapat menjadi media pembelajaran yang efektif, menyenangkan dan menarik karena disajikan dengan ilustrasi animasi dan gambaran secara nyata, serta dapat membantu pemahaman siswa mengenai materi siklus air, dan menumbuhkan kesadaran pentingnya menjaga lingkungan. Tujuan penelitian ini adalah untuk menciptakan media pembelajaran audio visual berbasis konservasi lingkungan pada topik siklus air kelas $\mathrm{V}$ sekolah dasar dan untuk mengembangkan media pembelajaran audio visual berbasis konservasi lingkungan pada topik siklus air kelas V sekolah dasar yang teruji validitasnya. Media pembelajaran audio visual ini diharapkan dapat meningkatkan motivasi siswa dalam belajar, membantu pemahaman siswa, serta menumbuhkan sikap peduli lingkungan, serta membantu dalam proses pembelajaran.

\section{METODE}

Jenis penelitian ini adalah penelitian pengembangan. Model pengembangan yang digunakan dalam penelitian ini adalah model 4D yang terdiri dari beberapa tahapan, yaitu tahap pendefinisian, tahap 
perancangan, tahap pengembangan, dan tahap peyebaran. Kegiatan yang dilakukan pada tahap pendefinisian adalah mengumpulkan informasi yang dibutuhkan dengan melaksanakan beberapa analisis, yaitu analisis awal-akhir, analisis peserta didik, analisis konsep, analisis tugas, serta perumusan tujuan pembelajaran. Pada tahap perancangan dilaksanakan pemilihan media yang tepat dan sesuai dengan situasi dan kondisi peserta didik, pemilihan format, serta rancangan awal berupa storyboard dan naskah. Pada tahap pengembangan dilakukan pengembangan media pembelajaran yang telah dikonsultasikan kepada dosen pembimbing, melaksanakan uji coba melalui review dari keempat pakar (2 dosen pembimbing, pakar media dan desain pembelajaran), 2 praktisi, dan 22 siswa kelas V SD untuk mendapatkan respon terkait dengan pengembangan media, serta melaksanakan perbaikan berdasarkan review yang didapat. Pada tahap penyebaran dilaksanakan dengan menyebarkan media pembelajaran audio visual berbasis konservasi lingkungan yang telah dikembangkan melaui Platform Youtube, sehingga media ini dapat diakses oleh guru dan siswa dalam proses pembelajaran.

Subjek penelitian ini adalah media pembelajaran audio visual berbasis konservasi lingkungan pada topik siklus air kelas $\mathrm{V}$ sekolah dasar yang akan diuji kepada 4 pakar (2 doesen pembimbing, pakar desain dan media pembelajaran), 2 praktisi, serta 22 siswa kelas V SD (respon perorangan kepada 6 orang siswa dan respon kelompok kecil kepada 16 orang siswa). Sedangkan objek penelitian ini adalah validitas media pembelajaran audio visual berbasis konservasi lingkungan pada topik siklus air kelas $\mathrm{V}$ sekolah dasar. Jenis data pada penelitian ini yaitu data kualitatif dan data kuantitatif. Metode pengumpulan yang digunakan dalam penelitian ini adalah metode kuesioner/angket. Instrumen yang digunakan dalam penelitian ini yaitu rating scale dengan skala 1-5. Terdapat dua jenis instrumen dalam penelitian ini, yaitu instrumen untuk pakar dan praktisi, serta instrumen untuk uji perorangan dan kelompok kecil. Adapun kisi-kisi validasi media pembelajaran audio visual berbasis konservasi lingkungan terdapat pada Tabel 1 , 2,3 , dan 4 .

Tabel 1. Kisi-kisi Instrumen Pakar dan Praktisi dari Aspek Isi Mata Pelajaran

\begin{tabular}{|c|c|c|c|}
\hline No & Aspek & Indikator & $\begin{array}{l}\text { Jumlah } \\
\text { Butir }\end{array}$ \\
\hline \multirow[t]{2}{*}{1.} & Ketepatan materi & Kesesuaian materi dengan tujuan pembelajaran & 1 \\
\hline & & Tujuan pembelajaran sudah menggunakan format ABCD & 1 \\
\hline \multirow[t]{2}{*}{2.} & Keakuratan materi & Kebenaran materi yang disampaikan & 1 \\
\hline & & Ketepatan penyajian materi berdasarkan fakta yang ada & 1 \\
\hline \multirow[t]{2}{*}{3.} & Penyajian tata & Ketepatan tata bahasa yang digunakan & 1 \\
\hline & bahasa & Ketepatan penulisan ejaan pada materi & 1 \\
\hline 4. & Penyajian tanda baca & Ketepatan penggunaan tanda baca pada materi & 1 \\
\hline \multirow[t]{4}{*}{5.} & Kesesuaian tingkat & Tingkat keluasan materi sesuai dengan karakteristik siswa & 1 \\
\hline & kesulitan materi & Materi awal mampu berkaitan dengan pengetahuan awal siswa & 1 \\
\hline & dengan pengguna & $\begin{array}{l}\text { Ilustrasi yang ditampilkan pada media pembelajaran mampu } \\
\text { memperjelas materi yang disampaikan }\end{array}$ & 1 \\
\hline & & Jumlah & 10 \\
\hline
\end{tabular}

Tabel 2. Kisi-kisi Instrumen Pakar dan Praktisi dari Aspek Desain Pembelajaran

\begin{tabular}{cclc}
\hline No & \multicolumn{1}{c}{ Aspek } & \multicolumn{1}{c}{ Indikator } & Jumlah Butir \\
\hline 1. & Ketepatan & Kesesuaian konten media audio visual dengan & 1 \\
& & karakteristik siswa. & \\
& & Materi dalam media audio visual dikemas secara runtut. & 1 \\
2. & \multirow{2}{*}{ Kejelasan } & Bahasa yang digunakan mudah dipahami siswa. & 1 \\
& & Kejelasan uraian dan pembahasan & 1 \\
3. & \multirow{2}{*}{ Kebermanfaatan } & Memudahkan pemahaman siswa terhadap materi. & 1 \\
& & Memotivasi minat belajar siswa. & 1 \\
& & Meningkatkan perhatian siswa terhadap pembelajaran & 1 \\
4. & Desain Pesan & Warna gambar nyaman dipandang & 1 \\
& & Ketepatan ilustrasi dengan materi yang dijelaskan & 1 \\
& & Penyajian materi menarik & 1 \\
\hline
\end{tabular}


Tabel 3. Kisi-kisi Instrumen Pakar dan Praktisi dari Aspek Media Pembelajaran

\begin{tabular}{cclc}
\hline No & Aspek & \multicolumn{1}{c}{ Indikator } & Jumlah Butir \\
\hline 1. & Kualitas & Ketepatan visual dengan materi & 1 \\
& visual & Komposisi visual & 1 \\
& & Kejelasan gambar & 1 \\
2. & Kualitas & Kejelasan suara presenter & 1 \\
& audio & Kesesuaian sound effect yang digunakan & 1 \\
& & Ketepatan penggunaan musik latar & 1 \\
3. & Penggunaan & Ketepatan jenis huruf & 1 \\
& teks & Ketepatan ukuran huruf & 1 \\
4. & Penyajian & Audio visual yang disajikan sesuai dengan karakteristik siswa & 1 \\
& audio visual & Keidealan durasi audio visual dengan pengguna & 1 \\
\hline & & \multicolumn{10}{c}{ Jumlah } & $\mathbf{1 0}$ \\
\hline
\end{tabular}

Tabel 4. Kisi-kisi Instrumen Respon Siswa

\begin{tabular}{cllc}
\hline No & \multicolumn{1}{c}{ Aspek } & \multicolumn{1}{c}{ Indikator } & Jumlah Butir \\
\hline 1. & Penyajian materi & Materi yang disajikan jelas & 1 \\
& & Kalimat yang digunakan mudah dipahami & 1 \\
& & Contoh yang disajikan dalam materi mudah dipahami & 1 \\
2. & Kejelasan suara & Kejelasan suara presenter & 1 \\
3 & Menarik minat & Kemenarikan warna dan gambar & 2 \\
& siswa & Kemenarikan konten media audio visual & 1 \\
4. & Kebermanfaatan & Materi yang disampaikan mudah dipahami dan & 1 \\
& & dimengerti & 1 \\
& & Proses pembelajaran lebih menyenangkan & 1 \\
\hline & Memberikan fokus perhatian & $\mathbf{1 0}$ \\
\hline
\end{tabular}

Setelah instrumen dikembangkan, kemudian diuji validitas instrumen oleh pakar dengan menggunakan rumus CVR dan CVI. Metode dan teknik analisis data yang digunakan dalam penelitian ini yaitu analisis deskriptif kualitatif dan analisis deskriptif kuantitatif. Analisis deskriptif kualitatif dapat berupa kritik, saran, maupun masukan dari hasil review para pakar, praktisi, dan siswa terhadap media pembelajaran yang dikembangkan. Sedangkan, analisis deskriptif kuantitatif digunakan untuk menganalisis skor dari pakar, respon praktisi, dan respon siswa melalui lembar penilaian. Skor dari pakar dianalisis dengan menggunakan rumus indeks validasi Aiken untuk mengetahui tingkat validitas media pembelajaran yang dikembangkan. Sedangkan, skor yang diperoleh dari hasil uji respon praktisi dan siswa dianalisis dengan menggunakan rumus Mean yang kemudian dikonversikan dengan pedoman konversi skala lima untuk mendapatkan hasil validitas media pembelajaran yang dikembangkan (Koyan, 2012). Kriteria indeks validasi isi Aiken dan pedoman konversi skala lima disajikan pada Tabel 5 dan Tabel 6.

Tabel 5. Kriteria Indeks Validasi Isi Aiken

\begin{tabular}{cc}
\hline Indeks Validasi Aiken & Kriteria \\
\hline $0,8-1,00$ & Tinggi \\
$0,4-0,8$ & Sedang \\
$V \leq 0,4$ & Rendah \\
\hline
\end{tabular}

Tabel 6. Pedoman Konversi Skala Lima

\begin{tabular}{cc}
\hline Rentang Skor & Kualifikasi/Predikat \\
\hline $4<\overline{\mathrm{X}}<5$ & Sangat Baik \\
$3,34<\overline{\mathrm{X}}<4$ & Baik \\
$2,66<\overline{\mathrm{X}}<3,34$ & Cukup \\
$2<\overline{\mathrm{X}}<2,66$ & Tidak Baik \\
$1<\overline{\mathrm{X}}<2$ & Sangat Tidak Baik \\
\hline
\end{tabular}




\section{HASIL DAN PEMBAHASAN}

Hasil

Penelitian ini dilaksanakan bertujuan untuk mengembangkan media pembelajaran audio visual berbasis konservasi lingkungan pada topik siklus air kelas V sekolah dasar. Penelitian pengembangan media pembelajaran audio visual berbasis konservasi lingkungan pada topik siklus air kelas $\mathrm{V}$ sekolah dasar ini telah melalui serangkaian tahapan yang sesuai dengan prosedur model pengembangan 4D. Pemilihan model pengembangan 4D ini didasari atas kesederhanaan dari desain penyajiannya. Tahap model pengembangan $4 \mathrm{D}$ terdiri dari empat tahapan, yaitu tahap penefinisian, tahap perancangan, tahap pengembangan, dan tahap penyebaran.

Tahap pendefinisian dilaksanakan melalui beberapa tahapan, yaitu analisis awal-akhir, analisis peserta didik, analisis konsep, analisis tugas, dan perumusan tujuan pembelajaran. Tahap analisis awalakhir dilakukan melalui observasi, wawancara, dan penyebaran kuesioner pada guru kelas $\mathrm{V}$ sekolah dasar di Gugus IV Kecamatan Busungbiu. Dari hasil analisis awal-akhir ini ditemukan permasalahan yaitu guru lebih memfokuskan pembelajaran dalam bentuk penugasan yang berdamak pada motivasi belajar siswa rendah, serta guru sulit menanamkan nilai karakter pada materi pembelajaran. Dari permasalahan tersebut diperlukan sebuah pengembangan media pembelajaran audio visual yang berbasis dengan nilai karakter seperti konservasi lingkungan. Selanjutnya, hasil analisis peserta didik yaitu siswa akan lebih antusias belajar saat materi pembelajaran dikemas secara menarik dan dapat diamati secara langsung oleh siswa. Oleh karena itu media pembelajaran audio visual yang dikembangkan haruslah menarik dan sesuai dengan karakteristik siswa. Pada analisis konsep dilakukan dengan menganalisis silabus dan buku guru. Hasil analisis konsep ini yaitu penyusunan KD dan indikator yang merupakan acuan dalam penyusunan materi dalam media yang dikembangkan. Kompetensi dasar dan Indikator pembelajaran disajikan paa Tabel 7.

Tabel 7. Kompetensi Dasar dan Indikator Pembelajaran Topik Siklus Air Kelas V SD

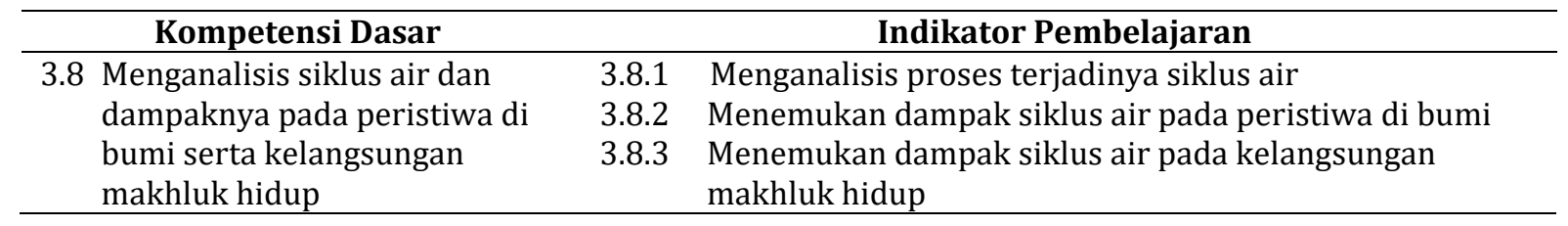

Selanjutnya, pada analisis tugas didapatkan hasil bahwa berdasarkan indikator yang disusun maka keterampilan yang diperlukan yaitu keterampilan membaca, menyimak, dan memahami. Sedangkan, pada tahap perumusan tujuan pembelajaran terdapat 3 tujuan yang telah dirumuskan, yaitu: 1) Dengan menyimak, siswa dapat menganalisis proses siklus air dengan benar; 2) Dengan menyimak, siswa dapat menemukan dampak siklus air bagi peristiwa di bumi dengan benar; 3) Dengan menyimak, siswa dapat menemukan dampak siklus air bagi kelangsungan makhluk hidup dengan benar.

Tahap perancangan dilakukan dengan penyusunan prototyope pembuatan produk media pembelajaran audio visual berbasis konservasi lingkungan berupa naskah dan storyboard. Rancangan naskah berisikan narasi di setiap adegan yang ditampilkan. Sedangkan, storyboard media pembelajaran audio visual berisikan sketsa gambar awal tiap adegan yang ditampilan dalam media audio visual. Storyboard dan naskah pembuatan media pembelajaran selanjutnya dilakukan bimbingan kepada dosen pembimbing untuk mendapatkan masukan dan saran dalam mengembangkan media. Selain itu, pada penelitian pengembangan media pembelajaran audio visual berbasis konservasi lingkungan pada topik siklus air kelas $\mathrm{V}$ sekolah dasar akan menghasilkan sebuah produk media pembelajaran audio visual dimana pembuatan opening, closing, dan ilustrasi siklus air dibuat pada aplikasi Microsoft Power Point, dan penggabungan video, green screen, backsound, sound track, dan transisi menggunakan bantuan aplikasi Kinemaster. Materi produk dalam penelitian ini berfokus pada materi dengan topik siklus air di kelas $\mathrm{V}$ sekolah dasar dengan durasi 12 menit. Selanjutnya rasio yang digunakan yaitu 16:9. Rancangan naskah dan storyboard disajikan pada Tabel 8.

Pada tahap pengembangan, media pembelajaran audio visual berbasis konservasi lingkungan mulai dikerjakan sesuai dengan rancangan yang telah disetujui oleh dosen pembimbing. Media pembelajaran audio visual yang dikembangkan terdiri dari pembuka, isi materi, dan penutup. Pada pembuka ditampilkan intro yang disajikan semenarik mungkin dengan warna yang nyaman dipandang. Pada intro video disajikan salam pembuka, identitas pengembang, topik pemahasan, KD, indikator pembelajaran, dan tujuan pembelajaran, serta disajikan dengan alunan musik lembut, sound effect yang sesuai, dan narasi. Bagian intro yang terdapat pada menit $00.01-01.15$. Selain itu juga disajikan menyapa siswa, mengaitkan materi pembelajaran dengan pengetahuan awal siswa, serta memberikan 
permasalahan yang dapat meningkatkan rasa ingin tahu siswa tehadap materi pembelajaran. Bagian pembuka pembelajaran terdapat pada menit 01.16 - 02.58. Pada bagian isi materi disajikan pembahasan materi pengertian siklus air, dampak terjadinya siklus air bagi bumi dan kelangsungan makhluk hidup, serta upaya pelestarian air bersih. Bagian isi materi akan diajikan ilustrasi siklus air serta disajikan gambar yang merupakan proses siklus air secara nyata, sehingga materi pembelajaran akan mudah dipahami siswa. Bagian isi materi terdapat pada menit 02.59 - 09.24. Pada bagian penutup disajikan memberikan refleksi, kesimpulan materi pelajaran, pemberian evaluasim dan salam penutup. Bagian penutup pembelajaran terdapat pada menit 09.25 - 11.44. Padat bagian penutup juga disajikan outro dengan menampilkan ucapan terimakasih dan credit teks, serta diiringi denganmusik gembira. Bagian outro terdapat pada menit 11.44 - 12.07. Tahap pengembangan disajikan pada Gambar 1.

Tabel 8. Rancangan Storyboard Media Pembelajaran Auio Visual

\begin{tabular}{|c|c|c|c|}
\hline Bagian & Isi & Sketsa Scene & Keterangan \\
\hline Opening & Menyapa siswa & $\begin{array}{l}\text { Narasi: } \\
\text { Menyapa siswa }\end{array}$ & $\begin{array}{l}\text { Jenis shot: Medium } \\
\text { Alat bantu: green screen, } \\
\text { tripod, microphone, dan } \\
\text { kamera handphone } \\
\text { Durasi: } \pm 22 \text { detik }\end{array}$ \\
\hline
\end{tabular}

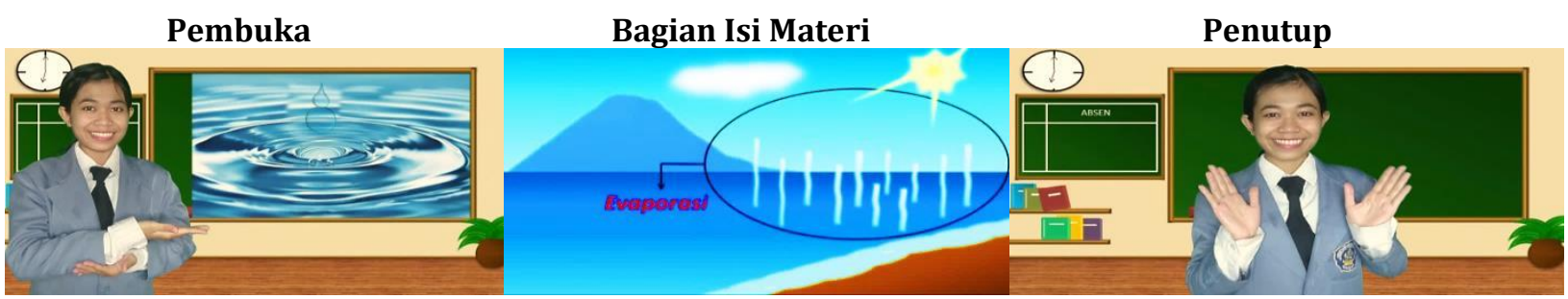

Gambar 1. Tahap Pengembangan Media Pembelajaran Audio Visual

Setelah media pembelajaran audio visual berbasis konervasi lingkungan telah melewati proses pengembangan, dilanjutkan dengan uji validitas oleh keempat pakar untuk mengetahui validitas media yang dikembangkan serta dilakukan analisis respon guru dan reapon siswa. Uji validitas dilakukan secara offline dan online dengan memberikan lembar penilaian kepada keempat pakar, dua praktisi dan dua puluh dua siswa kelas V SD. Hasil penilaian indeks validitas pakar disajikan pada Tabel 9.

Tabel 9. Rata-rata Skor Validitas Media Pembelajaran Audio Visual oleh Keenam Pakar

\begin{tabular}{lllc}
\hline \multicolumn{1}{c}{ Subjek Uji Coba } & \multicolumn{1}{c}{ Indikator } & Hasil Validitas & Kualifiasi \\
\hline 4 Pakar (2 dosen & Aspek Isi Mata Pelajaran & Rentang 0,813 - 1 & Tinggi \\
pembimbing, pakar media & Aspek Desain Pembelajaran & Rentang 0,813 - 1 & Tinggi \\
dan desain pembelajaran) & Aspek Media Pembelajaran & Rentang 0,938 - 1 & Tinggi \\
\hline
\end{tabular}

Berdasarkan hasil penilaian respon praktisi dengan menghitung skor rata-rata diperoleh bahwa, media pembelajaran audio visual berbasis konservasi lingkungan dari segi respon praktisi memperoleh rata-rata skor keseluruhan sebesar 4,97 yang berarti berada pada rentang $4<\mathrm{X} \leq 5$. Berdasarkan pedoman konversi skala lima, rata-rata skor pada rentang tersebut memiliki kualifikasi sangat baik. Selain itu, hasil penilaian respon siswa dilihat dari respon perorangan memperoleh skor rata-rata sebesar 4,83, dan respon siswa kelompok kecil memperoleh skor rata-rata 4,89, sehingga hasil skor respon siswa perorangan dan kelompok kecil berada pada rentang $4<\mathrm{X} \leq 5$. Berdasarkan pedoman konversi skala lima, rata-rata skor pada rentang tersebut memiliki kualifikasi sangat baik. Beberapa saran dan masukan yang didapat pada saat uji validitas yaitu warna teks dan background di kontraskan, suara backsound di kecilkan, serta menggunakan penomoran pada kesimpulan. Tahap penyebaran dilaksanakan dengan menyebarkan media pembelajaran audio visual berbasis konservasi lingkungan pada topik siklus air kelas V sekolah dasar melalui Platform Youtube, sehingga guru dan siswa dapat menggunakan media pembelajaran ini dalam proses pembelajaran. 


\section{Pembahasan}

Hasil penelitian menunjukkan bahwa media pembelajaran audio visual berbasis konservasi lingkungan pada topik siklus air kelas $\mathrm{V}$ sekolah dasar layak digunakan dalam menunjang proses pembelajaran IPA. Media pembelajaran audio visual berbasis konservasi lingkungan layak digunakan dalam proses pembelajaran dikarenakan beberapa hal, yaitu sebagai berikut. Pertama, media pembelajaran audio visual berbasis konservasi lingkungan pada topik siklus air kelas V sekolah dasar ini dapat meningkatkan motivasi belajar siswa karena disajikan secara inovatif, yaitu menyajikan nilai karakter peduli lingkungan dimana belum ada penelitian yang mengkaji mengenai media pembelajaran audio visual yang berbasis dengan konservasi lingkungan pada topik siklus air, menyajikan ilustrasi berupa animasi dan ilustrasi nyata yang dapat meningkatkan pemahaman siswa, serta menyajikan pertanyaan-pertanyaan yang dapat meningkatkan rasa ingin tahu siswa (Dwintasari \& Kurniawati, 2019; Purwadhi, 2019). Penyajian dan tampilan media pembelajaran audio visual berbasis konservasi lingkungan ini juga disesuaikan dengan karakteristik siswa, yaitu durasinya disesuaikan, pergerakan pergantian tampilan disesuaikan, intonasi suara jelas dan sesuai, serta menyajikan ilustrasi-ilustrasi yang sesuai dengan bahasan materi. Materi yang disajikan dengan ilustrasi berupa video animasi maupun gambar secara nyata dapat memperjelas materi pembahasan (Armansyah et al., 2019; Pradana et al., 2020). Selain itu, media pembelajaran ini ditampilkan secara menarik, karena media ini menyajikan visualisasi yang memiliki resolusi tinggi, warna yang digunakan nyaman dipandang, serta menyajikan audio berupa backsound dan sound effect yang dapat memberikan suasana, sehingga dapat meningkatkan minat belajar siswa (Fitriani et al., 2020; Mustofa et al., 2018).

Kedua, media pembelajaran audio visual berbasis konservasi lingkungan pada topik siklus air kelas V sekolah dasar ini layak digunakan dalam proses pembelajaran IPA karena memudahkan pemahaman siswa mengenai materi siklus air. Media pembelajaran ini menyajikan kompetensi dasar, indikator, serta tujuan pembelajaran agar siswa mengetahui apa saja yang mereka pelajari dengan media pembelajaran ini. Media pembelajaran audio visual berbasis konservasi lingkungan ini menyajikan pembahasan mengenai proses siklus air dan dampaknya dengan menampilkan ilustrasi yang sesuai, serta menampilkan gambaran nyata. Adanya ilustrasi gambar ini dapat mengatasi keterbatasan pengamatan siswa (Jampel \& Puspita, 2017; Takaeb \& Mone, 2018). Media pembelajaran audio visual ini juga menyajikan pembahasan mengenai konservasi lingkungan yang berkaitan dengan siklus air, menyajikan contoh upaya dan tindakan pelestarian lingkungan, serta menyajikan ajakan untuk peduli lingkungan. Dengan adanya contoh dan ajakan melakukan konservasi lingkungan maka kesadaran dan sikap siswa untuk peduli terhadap lingkungan akan tumbuh (Purwanti, 2017; Rif'ah, 2020). Selain itu, media ini juga menyajikan refleksi, bahasa yang digunakan sudah sesuai dengan kaidah bahasa Indonesia, bersifat komunikatif, serta tingkat bahasa yang digunakan disesuaikan dengan taraf kognitif siswa sekolah dasar, sehingga pembahasan materi mudah dipahami siswa kelas V sekolah dasar (Bigelow et al., 2021; Naldi, 2018).

Oleh karena itu, media pembelajaran audio visual ini dapat membantu pemahaman dan meningkatkan motivasi belajar siswa. Hal ini didukung dari temuan penelitian sebelumnya menyatakan bahwa media pembelajaran audio visual dapat meningkatkan motivasi belajar siswa secara signifikan (Puteri et al., 2020; Salsabila et al., 2020). Temuan penelitian lainnya juga menyatakan bahwa media pembelajaran audio visual dapat meningkatkan dan berpengaruh terhadap hasil belajar siswa (Adittia, 2017; Maulidah \& Syakur, 2018). Kelebihan dari media pembelajaran audio visual berbasis konservasi lingkungan ini adalah media ini tidak hanya memberikan pengetahuan mengenai materi siklus air saja, namun juga memberikan pengetahuan mengenai konservasi lingkungan, serta menumbuhkan kesadaran pentingnya menjaga lingkungan. Dengan pengetahuan dan kesadaran tersebut akan tumbuh sikap peduli lingkungan. Pemaparan materi pada media ini juga diberikan ilustrasi baik berupa animasi dan gambar nyata, sehingga siswa memiliki motivasi belajar dan siswa mudah memahami materi. Keterbatasan penelitian ini yaitu penelitian ini hanya pada tahap validitas, tetapi tetap layak digunakan karena telah dilaksanakan uji validitas produk dengan kualifikasi sangat baik. Kontribusi penelitian pengembangan ini memberikan dampak kepada guru untuk terus berinovasi dalam menciptakan pembelajaran yang efektif, sehingga guru tidak menggunakan metode konvensional. Implikasi penelitian ini adalah media pembelajaran audio visual berbasis konservasi lingkungan dapat digunakan pada proses pembelajaran baik daring maupun luring khususnya pada topik siklus air untuk meningkatkan motivasi dan pemahaman siswa.

\section{SIMPULAN}

Media pembelajaran audio visual berbasis konservasi lingkungan pada topik siklus air kelas $\mathrm{V}$ sekolah dasar dinyatakan valid dan layak digunakan dalam proses pembelajaran. Media pembelajaran 
audio visual berbasis konservasi lingkungan ini dapat membantu guru dalam menyampaikan materi, khususnya materi pada topik siklus air dengan jelas dan menarik. Sehingga, membantu siswa dalam memahami materi pelajaran khususnya materi pada topik siklus air. Media pembelajaran audio visual berbasis konservasi lingkungan juga dapat membantu guru menanamkan nilai karakter peduli lingkungan kepada siswa, sehingga dengan menggunakan media ini siswa tidak hanya memperoleh pengetahuan mengenai siklus air, namun juga menumbuhkan kesadaran peduli lingkungan.

\section{DAFTAR PUSTAKA}

Adittia, A. (2017). Penggunaan Media Pembelajaran Audio Visual untuk Meningkatkan Hasil Belajar IPS pada Siswa Kelas IV SD. Mimbar Sekolah Dasar, 4(1), 9-20. https://doi.org/10.23819/mimbarsd.v4i1.5227.

Andersen, F., Danny, King, C. L., \& Gunawan, A. A. S. (2021). Audio Influence on Game Atmosphere during Various Game Events. Procedia Computer Science, 179, 222-231. https://doi.org/10.1016/j.procs.2021.01.001.

Andriani, Mushafanah, Q., \& Wardhana, M. Y. S. (2019). Keefektifan Media Roda Jelajah Indonesia terhadap Hasil Belajar Materi Tematik. International Journal of Elementary Education, 3(2), 194. https://doi.org/10.23887/ijee.v3i2.18528.

Armansyah, F., Sulton, \& Sulthoni. (2019). Multimedia Interaktif sebagai Media Visualisasi Dasar-Dasar Animasi. Jurnal Kajian Teknologi Pendidikan, 2(3), 224-229. https://doi.org/10.17977/um038v2i32019p224.

Arsyad, A. (2014). Media Pembelajaran. PT. Rajagrafindo Persada.

Aulia, J., Permana P, N. D., Zarkasih, Z., \& Nova, T. L. (2020). Meta-Analisis Pengaruh Penerapan Pendekatan Saintifik Berbantuan Komik terhadap Hasil Belajar IPA Siswa SMP. Journal of Natural Science and Integration, 3(1), 70. https://doi.org/10.24014/jnsi.v3i1.9617.

Bigelow, F. J., Clark, G. M., Lum, J. A. G., \& Enticott, P. G. (2021). The Mediating Effect of Language on the Development of Cognitive and Affective Theory of Mind. Journal of Experimental Child Psychology, 209, 105158. https://doi.org/10.1016/j.jecp.2021.105158.

Damsa, C., Langford, M., Uehara, D., \& Scherer, R. (2021). Teachers' Agency and Online Education in Times of Crisis. Computers in Human Behavior, 121, 106793. https://doi.org/10.1016/j.chb.2021.106793.

Dong, C., Cao, S., \& Li, H. (2020). Young Children's Online Learning during COVID-19 Pandemic: Chinese Parents' Beliefs and Attitudes. Children and Youth Services Review, 118, 105440. https://doi.org/10.1016/j.childyouth.2020.105440.

Dwintasari, Y., \& Kurniawati, F. (2019). Persepsi Siswa terhadap Instruksi Guru yang Mengembangkan Strategi Belajar Regulasi Diri. Persona:Jurnal Psikologi Indonesia, 8(1), 57-77. https://doi.org/10.30996/persona.v8i1.2280.

Fitriani, A. A., Ulfa, S., \& Adi, E. P. (2020). Pengembangan Video Pembelajaran Animasi Sistem Pernapasan Manusia debagai Upaya Mendukung Kebijakan Belajar di Rumah. JKTP Jurnal Kajian Teknologi Pendidikan, 3(3), 303-316. https://doi.org/10.17977/um038v3i32020p303.

Handayani, N. F., \& Gafur, A. (2020). Professionalism of Civics Teacher Facing Educational Challenges in the Era of the Covid-19 Pandemic. International Journal of Multicultural and Multireligious Understanding, 7(10). https://doi.org/10.18415/ijmmu.v7i10.2183.

Herff, S. A., Olsen, K. N., Anic, A., \& Schaal, N. K. (2019). Investigating Cumulative Disruptive Interference in Memory for Melodies, Words, and Pictures. New Ideas in Psychology, 55, 68-77. https://doi.org/10.1016/j.newideapsych.2019.04.004.

Hidayati, A. S., Adi, E. P., \& Praherdhiono, H. (2019). Pengembangan Media Video Pembelajaran untuk Meningkatkan Pemahaman Materi Gaya Kelas IV di SDN Sukoiber 1 Jombang. JINOTEP : Jurnal Inovasi Dan Teknologi Pembelajaran, 6(1), https://doi.org/10.17977/um031v6i12019p045.

Jampel, I. N., \& Puspita, K. R. (2017). Peningkatan Hasil Belajar Siswa Sekolah Dasar melalui Aktivitas Pembelajaran Mengamati Berbantuan Audiovisual. International Journal of Elementary Education, 1(3), 197. https://doi.org/10.23887/ijee.v1i3.10156.

Jena, P. K. (2020). Impact of Pandemic COVID-19 on Education in India. International Journal of Current Research (IJCR), 12(07). https://doi.org/10.31235/osf.io/2kasu.

Karlina, N., \& Setiyadi, R. (2019). The Use of Audio-Visual Learning Media in Improving Student Concentration in Energy Materials. PrimaryEdu - Journal of Primary Education, 3(1), 17. https://doi.org/10.22460/pej.v3i1.1229.

Koyan, I. W. (2012). Statistik Pendidikan Teknik Analisis Data Kuantitatif. Singaraja: Universitas 
Pendidikan Ganesha.

Mastura, \& Santaria, R. (2020). Dampak Pandemi Covid-19 terhadap Proses Pengajaran bagi Guru dan Siswa. Jurnal Studi Guru Dan Pembelajaran, 3(2). https://doi.org/10.30605/jsgp.3.2.2020.293.

Maulidah, \& Syakur, A. (2018). Pengaruh Media Audiovisual terhadap Hasil Belajar Bahasa Indonesia dalam Materi Dongeng Pada Murid Kelas V. JKPD (Jurnal Kajian Pendidikan Dasar), 3(1), 408. https://doi.org/10.26618/jkpd.v3i1.1169.

Mishra, L., Gupta, T., \& Shree, A. (2020). Online Teaching-Learning in Higher Education during Lockdown Period of COVID-19 Pandemic. International Journal of Educational Research Ope, 1, 100012. https://doi.org/10.1016/j.ijedro.2020.100012.

Mustofa, S. P., Wihidayat, E. S., \& Hatta, P. (2018). Can the Use of Video Learning Increase Student's Interest in Traditional Music? IJIE (Indonesian Journal of Informatics Education), 2(1), 13. https://doi.org/10.20961/ijie.v2i1.12998.

Naldi, H. (2018). Perkembangan Kognitif, Bahasa dan Perkembangan Sosioemosional serta Implikasinya dalam Pembelajaran. Jurnal Socius: Journal of Sociology Research and Education, 5(2), 102. https://doi.org/10.24036/scs.v5i2.110.

Pattemore, A., \& Muñoz, C. (2020). Learning L2 Constructions from Captioned Audio-Visual Exposure: The $\begin{array}{lllll}\text { Effect of Learner-Related } & \text { Factors. }\end{array}$ https://doi.org/10.1016/j.system.2020.102303.

Pradana, D., Abidin, Z., \& Adi, E. P. (2020). Pengembangan Video Animasi Pembelajaran Subtema Pembentukan Karakter untuk Siswa SDLB Tunarungu. JINOTEP (Jurnal Inovasi Dan Teknologi Pembelajaran), 7(2), 96-106. https://doi.org/10.17977/um031v7i22020p096.

Pradilasari, L., Gani, A., \& Khaldun, I. (2019). Pengembangan Media Pembelajaran Berbasis Audio Visual pada Materi Koloid Untuk Meningkatkan Motivasi dan Hasil Belajar Siswa SMA. Jurnal Pendidikan Sains Indonesia, 7(1), 9-15. https://doi.org/10.24815/jpsi.v7i1.13293.

Purwadhi. (2019). Pembelajaran Inovatif dalam Pembentukan Karakter Siswa. Mimbar Pendidikan: Jurnal Indonesia Untuk Kajian Pendidikan, 21-34. https://doi.org/10.17509/mimbardik.v4i1.16968.

Purwanti, D. (2017). Pendidikan Karakter Peduli Lingkungan Dan Implementasinya. DWIJA CENDEKIA: Jurnal Riset Pedagogik, 1(2), 14-20. https://doi.org/10.20961/jdc.v1i2.17622.

Puteri, W. A., Maharani, D. A., \& Wulandari, A. (2020). Penggunaan Media Audio Visual Untuk Meningkatkan Motivasi Belajar Siswa selama Masa Pandemi Covid-19 pada Sd N 1 Serayu Larangan. ABDIPRAJA (Jurnal Pengabdian Kepada Masyarakat), 1(1), 122. https://doi.org/10.31002/abdipraja.v1i1.3146.

Putri, A., Kuswandi, D., \& Susilaningsih. (2020). Pengembangan Video Edukasi Kartun Animasi Materi Siklus Air untuk Memfasilitasi Siswa Sekolah Dasar. JKTP: Jurnal Kajian Teknologi Pendidikan, 3(4), 377-387. https://doi.org/10.17977/um038v3i42020p377.

Rahayu, N. N. D., Margunayasa, I. G., \& Fakhriyah, F. (2020). Alat Gerak Hewan dan Manusia Dikemas dalam Media Pop-Up Book. International Journal of Elementary Education, 4(2), 138. https://doi.org/10.23887/ijee.v4i2.24493.

Retnawati, H. (2016). Analisis Kuantitatif Instrumen Penelitian. Yogyakarta: Parama Publishing.

Rif'ah, R. (2020). Membangun Karakter Peduli Lingkungan melalui Prinsip Kebersihan. Jurnal Pendidikan Islam Indonesia, 4(2), 149-156. https://doi.org/10.35316/jpii.v4i2.188.

Safitri, M., \& Koeswanti, H. D. (2021). Pengembangan Media Pembelajaran "Kelas BANGTAR" Berbasis Adobe Flash untuk Meningkatkan Hasil BelajarMatematika Siswa Kelas IV Sekolah Dasar. Jurnal Cendekia: Jurnal Pendidikan Matematika, 589-1002. https://doi.org/10.31004/cendekia.v5i2.580.

Salsabila, U. H., Seviarica, H. P., \& Hikmah, M. N. (2020). Urgensi Penggunaan Media Audiovisual dalam Meningkatkan Motivasi Pembelajaran Daring di Sekolah Dasar. INSANIA: Jurnal Pemikiran Alternatif Kependidikan, 25(2), 284-304. https://doi.org/10.24090/insania.v25i2.4221.

Saputri, D. Y., Rukayah, \& Indriayu, M. (2018). Need Assessment of Interactive Multimedia Based on Game in Elementary School: A Challenge into Learning in 21st Century. International Journal of Educational Research Review, 3(3), 1-8. https://doi.org/10.24331/ijere.411329.

Sari, A. P., \& Setiawan, A. (2018). The Development of Internet-Based Economic Learning Media using Moodle Approach. International Journal of Active Learning, 3(2), 100-109. http://journal.unnes.ac.id/nju/index.php/ijal.

Satrianingrum, A. P., \& Prasetyo, I. (2020). Persepsi Guru Dampak Pandemi Covid-19 terhadap Pelaksanaan Pembelajaran Daring di PAUD. Jurnal Obsesi : Jurnal Pendidikan Anak Usia Dini, 5(1), 633. https://doi.org/10.31004/obsesi.v5i1.574.

Selvaraj, A., Radhin, V., KA, N., Benson, N., \& Mathew, A. J. (2021). Effect of Pandemic Based Online 
Education on Teaching and Learning System. International Journal of Educational Development, 85, 102444. https://doi.org/10.1016/j.ijedudev.2021.102444.

Silverman, R. D., Artzi, L., McNeish, D. M., Hartranft, A. M., Martin-Beltran, M., \& Peercy, M. (2019). The Relationship Between Media Type and Vocabulary Learning in a Cross Age Peer-Learning Program for Linguistically Diverse Elementary School Students. Contemporary Educational Psychology, 56, 106-116. https://doi.org/10.1016/j.cedpsych.2018.12.004.

Solekhah, H. (2020). Distance Learning of Indonesian Early Childhood Education (PAUD) during the Covid19 Pandemic. International Journal of Emerging Issues in Early Childhood Education, 2(2), 105115. https://doi.org/10.31098/ijeiece.v2i2.409.

Suryansah, T., \& Suwarjo. (2016). Pengembangan Video Pembelajaran untuk Meningkatkan Motivasi dan Hasil Belajar Kognitif Siswa Kelas IV SD. Jurnal Prima Edukasia, 4(2), 209. https://doi.org/10.21831/jpe.v4i2.8393.

Sutrisno. (2020). Meningkatkan Motivasi Belajar Siswa Melalui Layanan Bimbingan Kelompok Dengan Media Video-klip Info Artikel Abstract. Inopendas Jurnal Ilmiah Kependidikan, 3(1), 22-27. https://doi.org/10.24176/jino.v2i2.4528.

Takaeb, M. J., \& Mone, F. (2018). Pengaruh Model Pembelajaran Cooperative Tipe Group Investigation Berbantuan Media Gambar Terhadap Prestasi Belajar Siswa Kelas VIII SMP Negeri 3 Soe. Jurnal Sains Dan Edukasi Sains, 1(2), 33-38. https://doi.org/10.24246/juses.v1i2p33-38.

Tegeh, I. M., Jampel, I. N., \& Pudjawan, K. (2014). Model Penelitian Pengembangan. Yogyakarta Graha Ilmu.

Wardani, A., \& Ayriza, Y. (2020). Analisis Kendala Orang Tua dalam Mendampingi Anak Belajar di Rumah Pada Masa Pandemi Covid-19. Jurnal Obsesi: Jurnal Pendidikan Anak Usia Dini, 5(1), 772. https://doi.org/10.31004/obsesi.v5i1.705.

Winarto, W., Syahid, A., \& Saguni, F. (2020). Effectiveness the Use of Audio Visual Media in Teaching Islamic Religious Education. International Journal of Contemporary Islamic Education, 2(1), 81107. https://doi.org/10.24239/ijcied.vol2.iss1.14.

Yazar, T., \& Arifoglu, G. (2012). A Research of Audio Visual Educational Aids on the Creativity Levels of 414 Year Old Children as a Process in Primary Education. Procedia - Social and Behavioral Sciences, 51, 301-306. https://doi.org/10.1016/j.sbspro.2012.08.163. 